\title{
Containing the Costs of Recurrent Gastro-Duodenal Ulcer Bleeding
}

\author{
Antonio Ponzetto $^{\mathrm{a}}$ Natale Figura ${ }^{\mathrm{b}}$ Alessia Ciancio $^{\mathrm{a}}$ \\ ${ }^{a}$ Department of Medical Sciences, University of Turin, Turin, Italy; ${ }^{b}$ Department of Medical, Surgical and \\ Neurological Sciences, University of Siena, Siena, Italy
}

Dear Editor,

The paper by Takatori et al. [1] was extremely interesting, as it reported about the very high risk of upper gastrointestinal (GI) bleeding in patients with previous diagnosis of gastro-duodenal ulcer (GDU). In this era where there is a much focus on cost-containment and cost-cutting of hospital facilities, this study throws light on effective ways of reducing medical costs in the eradication of Helicobacter pylori infection, which is a known cause of GDU and GI bleeding. Takatori et al. [1] reported that it was almost impossible to ascertain whether or not these bleeding patients, observed in 2011-2014, had received testing for $H$. pylori infection, and cure for it, at the time they were diagnosed with GDU. Ulcer recurrence in the first year occurred in twothirds of patients carrying $H$. pylori and who failed to respond to curative treatment in Japan [2], while we and others in Italy observed almost zero recurrence of duodenal ulcer in the same timeframe, if patients were successfully cured of the infection [3, 4]. However, in the United States, a country with very low prevalence of $H$. pylori infection among the white population, recurrence rate was reported to be $20 \%$ after cure of the bacterium [5]. This rate is nonetheless far lower than that of two-thirds of

A.P. conceived the Letter, all authors contributed to the writing. All authors approved the final version. The writing is submitted solely to Digestive Diseases. non-cured patients. Upper GI bleeding leads to the need for hospitalization, urgent endoscopy, and often of resuscitation and multiple blood transfusions; the costs are staggering when compared with those of testing for $H$. pylori, even without taking into account the risk of death and the days lost to work. We would like to stress the importance of performing multiple tests for this infectious agent in GDU patients, as very often, gastric biopsies give negative results at the time of bleeding as highlighted by the MaastrichtV/Florence consensus report [6]. Therapy failures are representing a further increasing problem [6]; one reason for it - in Italy - is the present set of guidelines developed for treatment, which physicians are bound to obey even if they are no longer efficacious. We believe that it is necessary to liberalize the therapies used in the treatment of $H$. pylori infection - in Italy - and that this will greatly reduce future costs of treating upper GI bleeding.

\section{Disclosure Statement}

None of the authors has anything to disclose. No funding or grants were received for this study.

\section{References}

1 Takatori Y, Kato M, Sunata Y, Hirai Y, Kubosawa Y, Abe K, et al: The role of history of gastroduodenal ulcer in patients with upper gastrointestinal bleeding. Dig Dis 2018;36:177-181.

2 Asaka M, Kato M, Sugiyama T, Satoh K, Kuwayama $\mathrm{H}$, Fukuda $\mathrm{Y}$, et al: Follow-up survey of a large-scale multicenter, double-blind study of triple therapy with lansoprazole, amoxicillin, and clarithromycin for eradication of Helicobacter pylori in Japanese peptic ulcer patients. J Gastroenterol 2003;38:339-347.

3 Ponzetto A, Pellicano R, Palmas F, Demarchi B, Rizzetto M: Cigarette smokers and non smokers suffer of duodenal ulcer relapse rarely after cure of Helicobacter pylori infection. Eur J Internal Med 1997;8:131.

4 Capurso G, Annibale B, Osborn J, D’Ambra G, Martino G, Lahner E, Delle Fave G: Occurrence and relapse of bleeding from duodenal ulcer: respective roles of acid secretion and Helicobacter pylori infection. Aliment Pharmacol Ther 2001;15:821-829.

5 Laine L, Hopkins RJ, Girardi LS: Has the impact of Helicobacter pylori therapy on ulcer recurrence in the United States been overstated? A meta-analysis of rigorously designed trials. Am J Gastroenterol 1998;93:1409-1415.

6 Malfertheiner P, Megraud F, O’Morain CA, Gisbert JP, Kuipers EJ, Axon AT, et al: Management of Helicobacter pylori infection-the Maastricht V/Florence Consensus Report. Gut 2017;66:6-30.

\section{KARGER}

(c) 2018 S. Karger AG, Basel

E-Mail karger@karger.com

www.karger.com/ddi
Antonio Ponzetto, MD

Department of Medical Sciences

University of Turin, Corso AM Dogliotti 14

IT-10126 Torino (Italy)

E-Mail antonio.ponzetto@unito.it, ponzettoa@yahoo.it 